\title{
THE REGISTRATION OF COMMUNIST-FRONT ORGAN- IZATIONS: THE STATUTORY FRAMEWORK AND THE CONSTITUTIONAL ISSUE
}

Because the Communist movement cannot attain all its goals through the single instrumentality of the Communist Party, it frequently resorts to the use of organizations which operate under Communist instruction, but are not openly associated with the Communist Party or the Communist movement. Lacking the broad purposes of the Party, these groups are utilized by the Communist movement for more specific aims. Their primary purpose is to extend Communist influence into areas where an openly Communist appeal would not receive support, a task they seek to accomplish by concealing their true goals behind a "high-sounding and attractive reform objective." 1 Appeals are aimed at narrow groups, with emphasis placed upon such factors as occupation, ${ }^{2}$ race, ${ }^{3}$ religion, ${ }^{4}$ and, most frequently, specific political causes. ${ }^{5}$

Front organizations are most often established by a small group of party sympathizers who will then undertake a general canvas of the populace for supporters. ${ }^{6}$ This nucleus will usually install as president a prominent figure who either will go along with the Communists, or will function as a mere figurehead. ${ }^{7}$ In the latter case, an executive committee ${ }^{8}$ or an executive secretary ${ }^{9}$ will be the actual guiding force of the organization, and these positions will be filled by Communists or Communist sympa-

1 See Staff of Senate Committee on the Judiciary, 84th Cong., 1st Sess., The Comanunist Party of the United States of America-What It Is-How It Works-A HaNDBOOK FOR AMERICANS 90 (Comm. Print 1955) [hereinafter cited as COMMMUNist PARTY].

2 Communrst PARTy 91 (naming as examples the National Lawyers Guild and the Photo League).

3 Id. at 92 (naming as examples the United Negro and Allied Veterans of America, the Council on African Affairs, and the National Negro Labor Council).

4 Ibid. (naming as examples the Methodist Federation for Social Action and the American Jewish Labor Council).

5 Id. at 91 (naming as examples the National Council of American-Soviet Friendship, the Trade Union Committee for the Repeal of the Smith Act, the Joint Anti-Fascist Refugee Committee, and others). It should be noted that the National Council was found by the Subversive Activities Control Board to be a Communist front and ordered to register under the Internal Security Act. This finding was reversed by the District of Columbia Court of Appeals. See text accompanying notes 50-51 infra.

6 See National Council of American-Soviet Friendship, Inc. v. SACB, 322 F.2d 375, 381-83, 389 (D.C. Cir. 1963) ; CommunisT PARTY 93.

7 See ibid.; cf. National Council of American-Soviet Friendship, Inc. v. SACB, supra note 6 , at 389 .

8 See Communist Party 93 ; cf. National Council of American-Soviet Friendship, Inc. v. SACB, 322 F.2d 375, 381 (D.C. Cir. 1963).

9 See American Comm. for Protection of Foreign Born v. SACB, 331 F.2d 53, 55-56 (D.C. Cir. 1963), vacated and remanded per curriam for stale record, 85 Sup. Ct. 1148 (1965); COMMUNIST PARTY 93. 
thizers. Less commonly, an organization independently formed will be taken over by the Party, and the positions of power will be assigned to Party members or sympathizers. ${ }^{10}$ These procedures guarantee that the particular organization will remain an instrument of the Communist Party.11

\section{The Internal Security Act of 1950}

The Internal Security Act of 1950 sought to inform the public of the connection between various organizations and the Communist movement. ${ }^{12}$ Its principal provisions require the registration of communist-front and communist-action organizations. ${ }^{13}$ These groups are defined in the following terms:

"Communist-front organizations" means any organization in the United States (other than a Communist-action organization ... ) which (A) is substantially directed, dominated, or controlled by a Communist-action organization and (B) is primarily operated for the purpose of giving aid and support to a Communist-action organization, a Communist foreign government, or the world Communist movement . . . . ${ }^{14}$

"Communist-action organization" means-(a) any organization . . . which (i) is substantially directed, dominated or controlled by the foreign government or foreign organization controlling the world Communist movement . . . and (ii) operates primarily to advance the objectives of such world Communist movement . . . and (b) any section, branch, fraction or cell of any organization defined in subparagraph (a) ....$^{15}$

A 1954 amendment extended the registration requirement to communistinfiltrated organizations. The third statutory class includes all organizations which are substantially directed, dominated or controlled by an individual or individuals who are, or who within the last three years have been, aiding or supporting a communist-action organization, a foreign government, or the world Communist movement. ${ }^{16}$

Several consequences flow from a final order to register. To begin with, an organization subject to such an order must file a statement con-

10 See $i d$. at 90 .

11 See Veterans of the Abraham Lincoln Brigade v. SACB, 331 F.2d 64, 70 (D.C. Cir. 1963), vacated and remanded per curiam for stale record, 85 Sup. Ct. 1153 (1965) ; American Comm. for Protection of Foreign Born v. SACB, 331 F.2d 53, 56 (D.C.' Cir. 1963), vacated and remanded per curiam for stale record, 85 Sup. Ct. 1148 (1965). (1951).

12 See McCarran, The Internal Security Act of 1950, 12 U. PITr. L. REv. 481

1364 Stat. 993 (1950), 50 U.S.C. $\$ 786$ (1958). The act defines the point at which a Board order becomes final. 64 Stat. 1002 (1950), 50 U.S.C. $\$ 793$ (b) (1958).

1464 Stat. 989 (1950), 50 U.S.C. \$782(4) (1958).

1564 Stat. 989 (1950), 50 U.S.C. $\$ 782(3)$ (1958).

1668 Stat. 777 (1954), 50 U.S.C. $\$ 782$ (4A) (1958). 
taining the name of the organization and the address of its principal office; the names and last known addresses of its officers; an accounting, as prescribed by the Attorney General, of all moneys received and expended; and, in the case of a communist-action organization, the names and addresses of all members of the organization. ${ }^{17}$

The statute further prescribes certain restrictions to be imposed upon the members of an organization subject to a final order to register. A1though one of these restrictions-denial of passport rights to members ${ }^{18}$ -was recently held to be an unconstitutional infringement upon the liberty guaranteed by the due process clause of the fifth amendment, ${ }^{10}$ statutory provisions still restrict the employment of these individuals at defense facilities or with the Government. ${ }^{20}$

Severe restrictions are also imposed upon the associations which are ordered to register. They must label all mail and broadcasts as having been disseminated by a Communist organization. ${ }^{21}$ They lose any taxexempt status ${ }^{22}$ with the consequence that their contributors can no longer claim tax deductions for gifts to the organization. Moreover, a ten thousand dollar fine is imposed for each failure to register after an order has become final, and each day is considered a separate failure. ${ }^{23}$ Thus far, however, the fifth amendment privilege against self-incrimination has prevented the Government from devising a successful method for penalizing an organization for a failure to register. ${ }^{24}$

This Note will examine the constitutionality of subjecting communistfront organizations to such restrictions. In order to gain perspective, consideration will first be directed to the registration proceedings, with particular emphasis being placed upon the statutory issues and practical problems raised in such litigation.

\section{Communist Fronts and the Registration Proceedings}

\section{A. Litigation History}

The initial determination of whether an association is a communistfront, communist-action, or communist-infiltrated organization is made by the Subversive Activities Control Board, which hears suits brought by

1764 Stat. 993-94 (1950), 50 U.S.C. \& 786(d) (1958).

1864 Stat. 993 (1950), 50 U.S.C. \$ 785 (1958).

10 Aptheker v. Secretary of State, 378 U.S. 500 (1964).

2064 Stat. 992 (1950), 50 U.S.C. \$784(a) (1958). It has been suggested that since there is no right to Government employment, the Government may constitutionally impose reasonable conditions on its availability. See Note, 51 Colum. L. REv. 606, 624 (1951) ; cf. 96 CoNG. Rec. 13732 (1950) (remarks of Representative Case). 2164 Stat. 996 (1950), 50 U.S.C. $\$ 789^{9}$ (1958). Compare Lamont v. Postmaster General, 85 Sup. Ct. 1493 (1965).

2264 Stat. $996-97$ (1950), 50 U.S.C. $\$ 790$ (1958). Since there is no right to a tax exemption, or to a tax deduction, these provisions probably raise no serious constitutional issues. See Note, 51 CoLUM. L. REv. 606, 624 (1951).

2364 Stat. 1002 (1950), 50 U.S.C. \$ 794(a) (1958).

24 See Communist Party v. United States, 331 F.2d 807 (D.C. Cir. 1963), cert. denied, 377 U.S. 968 (1964); cf. Communist Party v. Commissioner, 332 F.2d 325 (D.C. Cir. 1964). See generally Note, 112 U. PA. L. Rev. 394 (1964), for a discussion of the problems involved in registration of associations. 
the Attorney General. ${ }^{25}$ Board registration orders may be appealed to the Court of Appeals for the District of Columbia, ${ }^{26}$ but the findings of the Board, if supported by a preponderance of the evidence, are conclusive. ${ }^{27}$

From the adoption of the act to the end of 1963, the Attorney General had initiated twenty-three registration proceedings against alleged communist-front organizations, two proceedings against alleged communistinfiltrated groups, and one proceeding against an alleged communist-action group. ${ }^{28}$ The last litigation began in 1950, and after extended Board and court proceedings, the Supreme Court finally affirmed the Board's registration order in 1961.

Several significant factors appear from a review of these proceedings. It took the Board, on the average, a little under three years to dispose of a case from the time the Attorney General instituted proceedings. The time span between initiation of the proceedings and final disposition has averaged a little less than six years, and two cases are still pending after registration orders were vacated by the Supreme Court. In two cases the Board held that it lacked jurisdiction because of dissolution of the organization; in five cases it granted a petition of the Attorney General for dismissal without prejudice because of mootness, the Attorney General retaining the right to institute new proceedings; and in two other cases motions of the Attorney General to dismiss were granted. Excluding these nine cases, the average Board determination took a little less than three an one-half years, and the average time to final determination took a little more than nine years.

These figures, however, are not necessarily predictive of the length of future litigation, since several of the cases were held in abeyance by the court of appeals pending the final Supreme Court decision in the Communist Party case. Eliminating the time between the Board order and the Supreme Court decision in that case, the average time from the initiation of proceedings by the Attorney General to the final disposition of the litigation becomes a little less than four years. However, excluding the nine cases mentioned above, the average time becomes a little less than six years. This figure appears to be the best indication of the average time consumed in communist-front litigation, and affects the issues of mootness, stale evidence, and constitutionality, factors which will be discussed below.

2564 Stat. 998 (1950), 50 U.S.C. $\$ 792$ (1958). The act also provides for voluntary registration by a communist-action group or a Communist front, 64 Stat. 993 (1950), 50 U.S.C. $\$ 786$ (a), (b) (1958), but no organization has yet voluntarily registered.

2664 Stat. 1001 (1950), 50 U.S.C. $\$ 793$ (a) (1958). The District of Columbia Court of Appeals may in its discretion transfer the action to the circuit where the petitioner resides.

2764 Stat. 1001 (1950), 50 U.S.C. §793(a) (1958).

28 The information in this section was derived from the reports of the Subversive Activities Control Board and the reported opinions of the District of Columbia Court of Appeals. 
Besides the time factor there is a somewhat more tenuous inference which may be drawn from these facts relative to the Board's disposition of these cases. Of the twenty-three "front" and "infiltrated" cases decided by the Board, registration was ordered in fifteen-one of these subsequently being mooted by the court of appeals upon motion of the Attorney General. In the eight others, the Board independently found that it had no jurisdiction in two because of dissolution of the alleged front, and dismissed the other six on petition of the Attorney General, four of those six being dismissed without prejudice and reserving in the Attorney General the right to institute new proceedings. Thus, of the seventeen cases of which the Board independently disposed of, it found for the Attorney General in fifteen, and it found it had no jurisdiction on the ground of dissolution in two.

Only twelve of the fifteen registration orders handed down by the Board were appealed. Four of these were found to have become moot and were thus not affirmed but rather placed in an "indefinitely inactive status." Of the remaining eight, one was reversed, no appeal was allowed in another since the organization had dissolved and thus could not appeal, and six were affirmed. All issues were litigated in only two of these six, and both of those cases were remanded by the Supreme Court to take new evidence, the Court holding that the orders were based on stale records. The decisions in the other four cases were more restrictive: on appeal, the court decided in two cases only that the showing of dissolution had been insufficient, in one that there was an insufficient showing of dissolution and no constitutional basis for reversal, and in the last that there was no constitutional basis for reversal. Thus, of the twenty-three cases instituted by the Attorney General, only seven have so far resulted in final registration orders, and only two of these seven were completely litigated in a court.

In light of the paucity of instances of complete court review of the Board orders it is difficult to argue that the Board has rubber stamped the Attorney General's determinations. There may, however, be some credence to such a charge, since of the seventeen cases the Board has decided independently of the Attorney General, it has found for the Attorney General in fifteen, the other two having been decided on jurisdictional grounds. Court disposal has been too inconclusive to establish any pattern. Of the twelve cases which have been appealed, only six have been affirmed, but only two of these were complete litigations of all issues; and in five of the six which were not affirmed the court's decision was based solely on dissolution. Finally, in the one case reversed, the reversal was on the merits. Thus the court of appeals has decided the merits in only three cases, and has affirmed the Board in two. The Board, on the other hand, has found for the Attorney General in all fifteen cases it has disposed of on the merits. These figures are insufficient for any definite conclusions about the leanings of the Board, but they do indicate that the Attorney 
General apparently has a more sympathetic forum in the Board than in the courts. The Supreme Court's disposition of the two latest orders indicates that it will demand more of the Government-at least on evidentiary problems-than either the Board or the court of appeals has thus far.

\section{B. Statutory Requirements and Practicalities}

\section{Instability of Legal Entities}

Because the statutory provisions dealing with front organizations require registration of legal entities rather than of individuals, it is often necessary to determine whether an organization is still extant at the close of the registration proceedings or at the time of appeal. This problem is especially difficult where the organization ordered to register is unincorporated, for no easily ascertainable legal standard of existence is available in such a situation. The requirement of a legal entity appears to provide a means by which an organization could evade registration by simply disbanding upon the issuance of an order, and thereafter reorganizing in a new guise. If such a course of action were allowed, the Government would be seriously limited in its efforts to implement the statutory purpose.

While a defendant should not be permitted to moot a proceeding by its own voluntary acts, ${ }^{29}$ the court in the communist-front cases recognized that a different situation is presented when the organization ordered to register carries the burden of proof as to mootness. The court refused to affirm the registration orders in those cases and remanded the cases to the Board with orders to place them in "indefinitely inactive status." 30 The court's refusal to affirm was based on two grounds. To begin with, it argued that any order entered would be without identifiable substance, since it would lack either present or foreseeable effect upon any party to the proceedings. This reasoning is justified both by the statutory language, which is addressed to the present, and by the registration provision's design not to penalize, but rather to expose the organization to the public. The second ground-the effect on the members of an organization ordered to register-presents a broader argument against registration. When a registration order becomes final the act immediately places certain restrictions on the members of the front. Since the act does not provide a way for individuals to challenge an order, the continued existence of the latter after dissolution of the organization threatens members with penalties without affording them adequate protection. A member could, for example, be discharged or refused employment by the Government or by a defense

29 See Walling v. Helmerich \& Payne, Inc., 323 U.S. 37 (1944).

30 See, e.g., Haufrecht v. SACB, 322 F.2d 403 (D.C. Cir. 1963); Blau v. SACB, 322 F.2d 397 (D.C. Cir. 1963); Labor Youth League v. SACB, 322 F.2d 364 (D.C. Cir. 1963). In several cases the court rejected the argument of mootness. See, e.g., Jefferson School of Social Science v. SACB, 331 F.2d 76 (D.C. Cir. 1963); Patterson v. SACB, 322 F.2d 395 (D.C. Cir. 1963); California Labor School, Inc. v. SACB,
322 F.2d 393 (D.C. Cir. 1963). 
facility because of an order, and have no way to clear his name by court proceedings. ${ }^{31}$

Although the court would not affirm the orders, it refused to dismiss the cases for mootness. Remanding and placing the order in an "indefinitely inactive status," it preserved the entire Board record, and left open the possibility that the record would be reopened and the registration order issued again if the organization were reactivated.

An alternative solution to the problems in this area was advanced by the court of appeals in Jefferson School of Social Science v. SACB, ${ }^{32}$ in which the court added to the organization's burden as to mootness the necessity of showing that the organization had not been reorganized under a new name. Although the court carefully indicated that it was not deciding if the Board order would apply to the presently existing organization, ${ }^{33}$ it apparently gave its approval to a Board-formulated criteria which treated both organizations as identical for all purposes. ${ }^{34}$ This ruling might indicate that any organization which resembles a group earlier held to be a front will be required to register without benefit of litigation, thus being subjected to the penalties of the act without any hearing at all. It need hardly be added that such an approach would be seriously deficient.

\section{Court Review of the Board}

\section{a. Stale Evidence}

The prolongation of front registration proceedings has created another difficulty for the courts. Because the statute was interpreted as operating in the present, the court of appeals required the proof to be related to the present. However, the court did accept evidence of past activities as having probative value for the present. ${ }^{35}$ This was of great significance in the litigated cases, since the Board findings were related to events occurring no later than the mid-fifties. The court was concerned by the lack of evidence relating to the more immediate present, but this was not felt sufficient to sustain a reversal of a Board order to register. ${ }^{36}$ The court, however, rejected the argument that a showing of membership in the Communist Party during World War II was sufficient evidence to establish membership in the early fifties, in view of the changed political climate. ${ }^{37}$ But this limitation only applied to the timeliness of evidence at the Board hearings, and was not extended to require showing

31 See Labor Youth League v. SACB, supra note 30, at 372-73.

32331 F.2d 76 (D.C. Cir. 1963).

33 Id. at 81 .

34 See $i d$. at 85 (Bazelon, C.J., dissenting).

35 See, e.g., Veterans of the Abraham Lincoln Brigade v. SACB, 331 F.2d 64, 68 (D.C. Cir. 1963), vacated and remanded per curiam for stale record, 85 Sup. Ct. 1153 (1965).

${ }^{36}$ See Veterans of the Abraham Lincoln Brigade v. SACB, supra note 35, at 72-73.

37 See National Council of American-Soviet Friendship, Inc. v. SACB, 322 F.2d 375, 384 (D.C. Cir. 1963). 
relation to the time of court review, despite the fact that there may also have been fluctuations in the political climate during the years between the Board findings and court review.

The Supreme Court, in both the communist-front cases which reached it, vacated the registration orders on the ground that the records were too stale to form the basis for a registration order. The Court indicated that it would require not only that the evidence be timely in relation to the time of the Board hearings, which seemingly was the sole test of the court of appeals, but also that "reasonably current aid and control must be established to justify a registration order." 38 This means that the Government will have to keep its case timely through the entire litigation, which, in view of the time gap between board orders and court proceedings, may make the statute virtually unworkable.

\section{b. Limitations on Court Review}

In the Internal Security Act Congress specifically provided that Board findings of fact were to be upheld on review only where "the preponderance of the evidence" supports them, ${ }^{39}$ and not where there is merely "substantial evidence" reinforcing them. The legislative history indicates that this broad scope of review was granted to give greater protection to the individuals or organizations concerned, because political rather than economic rights were involved. ${ }^{40}$ There are, however, practical limits to court review of the Board's findings of fact. In National Council of American-Soviet Friendship, Inc. v. SACB, ${ }^{41}$ for example, the court indicated that since the record was so voluminous and unannotated, it would be under no obligation to consider portions of the record other than those cited by the parties.

A further limitation on effective court review is the vagueness of the statutory criteria. These criteria are: ${ }^{42}$

(1) the extent to which persons who are active in its [the front's] management, direction, or supervision, whether or not holding office therein, are active in the management, direction, or supervision of, or as representatives of, any Communist-action organization, Communist foreign government, or the world Communist movement . . . ; and

(2) the extent to which its support, financial or otherwise, is derived from any Communist-action organization, Communist

38 American Comm. for Protection of Foreign Born v. SACB, 85 Sup. Ct. 1148, 1149 (1965).

3964 Stat. 1001 (1950), 50 U.S.C. §793(a) (1958) ; see 94 Cong. REc. 6134-37 (1948); 96 CoNG. REC. 13765 (1950) (remarks of Representative Nixon); id. at 14531 (remarks of Senator Ferguson).

40 See ibid.

41322 F.2d 375 (D.C. Cir. 1963).

4264 Stat. 1002 (1950), 50 U.S.C. \&792(f) (1958). 
foreign government, or the world Communist movement . . . ; and

(3) the extent to which its funds, resources, or personnel are used to further or promote the objectives of any Communistaction organization, Communist foreign government, or the world Communist movement . . . ; and

(4) the extent to which the positions taken or advanced by it from time to time on matters of policy do not deviate from those of any Communist-action organization, Communist foreign government, or the world Communist movement . . . . ${ }^{43}$

The legislative history of the act indicates that all of these factors must be taken into consideration, but contains no indication of what weight, if any, is to be given to each. ${ }^{44}$ Thus court reversal of the Board is nearly impossible.

Another restriction on court review is provided by the possible financial inability of an organization to carry an appeal to the courts. ${ }^{45}$ When such a condition exists, the Board's finding is in fact unreviewable. Illustrative of the problem is Weinstock $v$. $S A C B, 46$ which involved a registration order against the United May Day Committee. There the organization appealed solely on constitutional arguments taken from a brief in another front case, since it could not afford to retain an attorney to present any other arguments. Thus the organization had no court review of the factual findings of the Board, and the board order was affirmed after the constitutional arguments in the incorporated brief had been rejected.

\section{Statutory Definition of a Communist Front}

\section{Control Element}

The statutory definition of a Communist front includes the two elements of control and purpose. To be labelled as a communist-front, an organization must first be found to be "stibstantially directed, dominated or controlled by a communist-action organization." 47 Since the element of control is extremely difficult to prove, the Supreme Court in the Communist Party case held that the Government was not obliged to show that

43 This last criteria was one of the most debated provisions in the act, and the one the opponents of the act most severely criticized. See, e.g., 96 CoNG. REc. 13735-40 (1950) (remarks of Representative Celler) ; id. at 13766 (remarks of Representative O'Hara); id. at 14192-3 (remarks of Senator Lehman); id. at 14196 (remarks of Senator Humphrey); $i d$. at 15678 (remarks of Senator Douglas).

44 See 96 Cong. REc. 14408-9 (1950) (remarks of Senator Douglas) ; id. at 14531 (remarks of Senator Graham).

45 See Chafee, The Blessings of Liberty 143 (1956).

46331 F.2d 75 (D.C. Cir. 1963).

4764 Stat. 989 (1950), 50 U.S.C. §782(4) (1958). 
the foreign government had power to enforce obedience to its will. The Court held sufficient proof of a consistent disposition, over an extended period of time, to follow the policies of the foreign government regardless of their content.48 For purposes of front litigations, it was also held that the Communist Party was a communist-action organization. ${ }^{49}$ In National Council of American-Soviet Friendship v. $S A C B, 50$ the court reversed the Board where the evidence showed only that the managers of the association were Party members and failed to show that they were either active in the management of the Party or acting as its representatives. To be classified as a communist-front, the court held, a group must be substantially directed by a communist-action organization, and not merely by members of such a group. The Board's contention that all members of the Party act as its representatives was rejected as both unrealistic and destructive of the distinction between a communist-front and a communistinfiltrated organization. ${ }^{51}$ That distinction would indeed appear to imply that before the much broader sanctions ${ }^{52}$ applicable to a communist-front organization can be invoked, a far greater linkage must be shown to à communist-action group than is provided by a mere overlap of membership.

\section{Purpose Element}

The statute includes a second element in its definition of a Communist front: an organization must be "primarily operated for the purpose of giving aid and support to a communist-action organization, a Communist foreign government, or the world Communist movement . . . ." $53 \mathrm{Al}$ though the court of appeals has had to deal with this provision in only two cases, different views of the section have already emerged.

In American Comm. for Protection of Foreign Born v. SACB,54 the defendant, through legal action and propaganda, concerned itself primarily with the defense of individuals involved in deportation and denaturalization proceedings. Those defended were not all members of the Communist Party, but the court apparently accepted the testimony of immigration officers before the Board that the "bulk" of the cases involved Party members. ${ }^{55}$ The propaganda activities of the Committee also contained

48 Communist Party v. SACB, 367 U.S. 1, 39-42 (1961); The Supreme Court, 1960 Term, 75 Harv. L. Rev. 80, 105 (1961); 26 Albany L. Rev. 95, 98 (1962).

49 See, e.g., Jefferson School of Social Science v. SACB, 331 F.2d 76, 82-83 (D.C. Cir. 1963). This conclusion was based upon the premise that once it was shown that an organization was controlled by the Party, the privity between that organization and the Party made the holding in the Communist Party case res judicata.

50322 F.2d 375 (D.C. Cir. 1963).

51 See note 16 supra and accompanying text for the statutory definition of a communist-infiltrated organization.

02 The major restriction on communist-infiltrated organizations is that the members cannot become officers or hold employment with any labor organization. 68 Stat. 777 (1954), 50 U.S.C. \$784(1) (E) (1958).

5364 Stat. 989-90 (1950), 50 U.S.C. \$782(4) (1958).

54331 F.2d 53 (D.C. Cir. 1963), vacated and remanded per curiam for stale record, 85 Sup. Ct. 1148 (1965).

55331 F.2d at 60 . 
what the court characterized as "notable Party overtones." 56 Moreover, it was found that the aims of the Committee were aims of the Communist Party. ${ }^{\text {.7 }}$

In Veterans of the Abraham Lincoln Brigade v. $S A C B, 58$ the appellant claimed that its chief activities were social affairs, statements in opposition to the Franco regime, rehabilitation of Brigade members in need of aid, support of members indicted under the Smith Act, and defense of itself in the registration proceedings..$^{58}$ The court viewed the evidence as showing that the Brigade's principal interest was the defense of two members indicted under the Smith Act, with opposition to Franco next in importance. 60 What ostensibly were social gatherings were held to have been conducted principally for the defense of a member indicted under the Smith Act. The court noted that admission was charged, collections were taken up, and impassioned pleas were made in his behalf. ${ }^{61}$ The Brigade publication charged the Truman administration "with all sorts of misdoing in its relations with Franco," 62 made "continuous attacks on the Internal Security Act, Senator McCarran, the Un-American Activities Committee, the Wall Street Imperialists, and all warmongers," and demanded cessation of the Korean War. ${ }^{63}$ The court characterized all of these activities as aims and purposes of the Communist Party. ${ }^{64}$

\section{a. Extent of Illegal Activities}

The statute requires an organization which is to be classified as a Communist front to be operated "primarily" for the purpose of aiding and supporting certain Communist groups or causes." In American Committee the majority opinion suggested that the word "primarily" may only mean "substantially," 68 citing as its sole support a Supreme Court decision "7 construing the word "primarily" in a section of the 1933 Banking Act. In dissent, Judge Bazelon gave "primarily" the meaning of "principally" or "chiefly," stressing that the word "substantially" was used by Congress in the immediately preceding "control" section of the definition. ${ }^{88}$ However, the majority's construction may in practice not differ greatly from that of Judge Bazelon, since the court, in discussing

56 Ibid.

57 Ibid.

58331 F.2d 64 (D.C. Cir. 1963), vacated and remanded per curiam for stale record, 85 Sup. Ct. 1153 (1965).

59 Id. at 66.

60 Id. at 72 .

61 Id. at 73.

62 Id. at 72 .

63 Ibid.

64 Ibid.

6564 Stat. 989, (1950), 50 U.S.C. \$782(4) (1958).

66331 F.2d at 57.

67 Board of Governors v. Agnew, 329 U.S. 441 (1947).

68331 F.2d at 61 n.2. 
the facts in American Committee, referred to a "major portion" of the efforts of the organization. ${ }^{69}$ If the court will require a showing that a "majority" of an organization's actions have the proscribed purpose, the differences from Judge Bazelon's formulation become imperceptible. Nevertheless, Judge Bazelon's criticism of the majority interpretation is supported by the only legislative history on this point. In arguing that the act was constitutional, Senator Ferguson, whose earlier bill was one of those which formed the basis for the act, underscored the word "primarily" and pointed out that it had been deliberately used to narrow the reach of the statute. $^{70}$ Thus the majority's suggestion that "primarily" may be interpreted to mean "substantially" should be rejected by the Supreme Court.

It is important to note, however, that these differing interpretations had no effect on the outcome in either case. In Veterans of the Abraham Lincoln Brigade, the court did not even advert to this point; in American Committee, after stating that "primarily" may mean "substantially," the court never again referred to the issue. It is thus difficult to assert with confidence what the court regards "primarily" to include. Even if the differences in interpretation are regarded as significant, however, the impact on future cases will probably be negligible, since most of the organizations involved are devoted almost exclusively to a single set of activities.

\section{b. The Object of the Organization's Activities}

In the two cases in which the court specifically dealt with the purpose element, none of the activities which the organization pursued were in themselves illegal. Recognizing this, the majority in Veterans of the Abraham Lincoln Brigade phrased the purpose test in the following manner:

When a person, or an organization, actively presses objectives which are objectives of the Communist Party, does he do so as a matter of independent conviction, or does he do so by reason of substantial direction or control by the Communist Party and for the purpose of giving aid and support to the party ? ${ }^{71}$

Although the court did not refer to this test in American Committee, that opinion does state that the act "seeks the registration of any organization the purpose of which, under control of the Party, by any activity, laudable or otherwise, is to strengthen the power of the Communist Party in this country." 72 There would thus seem to be a merging in both opinions of the control and purpose elements. Indeed, the court never treats the latter as a truly separate and independent component, and devotes

69 Id. at 57 .

7096 Cong. Rec. 14530 (1950) (remarks of Senator Ferguson).

71331 F.2d at 72.

$72 I d$. at 58 . 
the bulk of its opinions to the control factor. Nor do the majority differentiate between activities which are or are not protected by the first amendment, reading the purpose element literally as asking only whether the organization is operated for the purpose of giving aid and support to the Communist Party.

Judge Bazelon dissented in both American Committee and Veterans of the Abraham Lincoln Brigade, contending that the majority had misconstrued the purpose element. Judge Bazelon's construction rests upon the premise that only those activities which advance the world Communist movement's objective to overthrow the Government and to replace it with a totalitarian dictatorship bring the Communist Party within the statutory definition of a communist-action organization. Accordingly, a front is seen as an organization operated for the purpose of aiding a communistaction organization in such activities.

This restricted construction was seen by Judge Bazelon as a way of avoiding serious constitutional problems raised by the majority position. Since Bazelon believed that the registration of the Communist Party was sustained only because that organization was operated primarily for the purpose of overthrowing the Government and establishing a totalitarian dictatorship, he doubted that registration could be required of an organization-such as a Communist front under the majority definition-which pursued other aims. Furthermore, he pointed to the severe and identical penalties imposed upon both Communist fronts and communist-action organizations, arguing that Congress had no intention of inflicting them upon members of an organization which is pursuing legal aims, but which, unknown to them, is controlled by the Communist Party.

Judge Bazelon's construction of the purpose element seems a strained reading of the statute, for the act apparently covers any type of purpose to aid the Communist movement. Indeed, the act was designed to ferret out all Communist-influenced organizations, not just those directly seeking to overthrow the Government. Communist fronts, moreover, are particularly difficult for the public to identify, yet in some degree they operate to support the Communist movement. Judge Bazelon's test, however, would make communist-front organizations virtually indistinguishable from communist-action organizations, allowing many groups to escape the registration requirement although the act clearly intended broader coverage. ${ }^{73}$ Finally, the severity of penalties seems an inadequate reason for a narrow definition of a front organization, since the act requires production of membership lists only in the case of communist-action organizations. Such an approach recognizes that there will often be innocent members in a front organization, advancing what to them are legal objectives. ${ }^{74}$ The innocent individual could thus remain anonymous and sever his connection with the group upon learning of an order to register. (1951).

${ }^{73}$ See McCarran, The Internal Security Act of 1950, 12 U. PITr. L. Rev. 481

74 Compare Aptheker v. Secretary of State, 378 U.S. 500, 510-11 (1964). 
Although there are admittedly severe effects on members of a front organization ordered to register, such effects can to a great extent be mitigated by voluntary withdrawal. Moreover, in overemphasizing the effects on the members, Judge Bazelon seems to have lost sight of Congress' basic aim, which was to affect the organization as a tool of the Communist movement. Judge Bazelon's desire to avoid the constitutional questions by narrowly construing the act seems inappropriate in this instance, for where the effect of a narrow construction would be to emasculate a statute, the constitutional issue should be directly confronted, rather than avoided.

The majority's construction of the purpose provision seems more consonant with the statutory intent. ${ }^{75}$ Although the statute, because it contains a specific purpose criterion, cannot strictly be interpreted to say that all groups controlled by communist-action organizations have the requisite purpose, the practical effect of a reading which relegates the purpose element to a minor role would still appear sound, as an organization controlled by a communist-action group will nearly always have as its purpose the aid and support of that group. The majority formulation would thus seem to come closer to congressional intent than that of Judge Bazelon, and its test will effectuate the aim of the statute.

\section{FreEdom of Association and the Registration of Communist Fronts}

In view of the severity of the restrictions imposed upon communistaction and communist-front organizations by the Internal Security Act, a collision with the constitutional doctrine of freedom of association seems inevitable. While Congress was aware at the time of enactment that the registration scheme presented first amendment problems, the Court had not at that time fully articulated a concept of freedom of association. Subsequent to passage of the act, however, the Court greatly expanded the constitutional protection of associations and the registration provisions of the act were first challenged in Communist Party $v . S A C B{ }^{78}$ In that case, an order directing the registration of a communist-action organization-the Communist Party-was held constitutional by the Court. Although there were four dissents on the ground that the registration requirement violated the fifth amendment freedom against self-incrimination, only Justice Black dissented on the additional ground that the registration

75 The legislative history, however, is unclear. The question of Communist fronts was the most debated one in the act, and the constitutionality of the registration provision was continually questioned. There is a statement, by one of the bill's supporters, that it is clear that the provisions for registration apply only to organizations whose essential aims "are to further the objectives of a foreign government or of the world Communist movement under the domination of foreign control"-this at a time when the purpose element of the definition included giving aid and support to a Communist political organization (the term in the Senate bill which was replaced by communist-action organization in the enacted version)-but it is not clear whether the speaker was addressing himself directly to an interpretation of the Communist front provisions. 96 CoNG. REC. 14257 (1950) (remarks of Senator O'Conor).

76367 U.S. 1 (1961). 
order was an unconstitutional infringement of first amendment rights. The majority narrowly confined its holding to the validity of the registration requirement, finding that it did not violate the first amendment freedoms of expression and association. All other constitutional questions concerning the operation of the statute were held to be raised prematurely since Congress had provided a separability clause in the event that any part of the act was held unconstitutional. Since this narrow decision by no means settles the constitutionality of the registration of front organizations, ${ }^{77}$ it is necessary to review the development of the doctrine of freedom of association in order to assess the constitutional position occupied by this decision and its likely impact upon the registration of front organizations.

\section{A. Freedom of Association}

The recognition of freedom of association as a constitutionally protected right is a relatively recent development. ${ }^{78}$ Claims for constitutional protection of associations were originally couched solely in terms of liberty under the due process clause of the fourteenth amendment, and could thus yield to a proper exercise of police power. In New York ex rel. Bryant v. Zimmermann, ${ }^{79}$ for example, the Court passed upon the constitutionality of a state statute that imposed a criminal penalty upon those retaining membership in the $\mathrm{Ku}$ Klux Klan with knowledge that the organization had failed to comply with a state registration statute. The Court held that a showing of nonarbitrariness and likely effectiveness was sufficient to sustain the constitutionality of the statute in the face of an attack based on fourteenth amendment liberty. Decided in 1928, Bryant remained as a strong precedent against the development of a doctrine of freedom of association.

A significant change in the Court's attitude toward the scope of the constitutional protection to be afforded associations appeared in Thomas v. Collins, ${ }^{80}$ decided in 1945 . In Thomas the Court held that a state statute requiring a labor organizer to obtain a card before soliciting memberships for his union could not constitutionally be applied to a speech by a union official in which he invited his audience to join a union. The requirement was held to be incompatible with the exercise of free speech and free assembly. The significance of Thomas lay in the fact that a majority of the Court viewed the constitutional rights of an association as emanating from a broadly based first amendment freedom to express ideas. This

77 See American Comm. for Protection of Foreign Born v. SACB, 85 Sup. Ct. 1148,1149 n.2 (1965).

78 The concept of freedom of association was first clearly enunciated in NAACP v. Alabama ex rel. Patterson, 357 U.S. 449 (1958). For the early history of this freedom, see generally FellMan, The Constirutional RigET OF Association 1-12 (1963). Fellman links the freedom to freedom of assembly. It seems, however, that the concept is more related to freedom of speech, since it is a cognate of the first amendment rights insuring freedom to express ideas. See text accompanying notes 81,86 infra.

79278 U.S. 63 (1928).

80323 U.S. 516 (1945). 
freedom was seen to encompass freedom of speech and freedom of assembly in Thomas, and has now expanded to comprehend a freedom of association. The expansion was a natural development once the Court recognized that the rights protected by the first amendment are truly inseparable-that they are cognate rights, ${ }^{81}$ all aiming at the protection of political expression. Recognition was thus implicitly given in Thomas to the essential role that freedom of association has in a present-day constitutional democracy, where an individual can effectively function politically only if he is free to associate without undue restraint. ${ }^{82}$ Although the case did not directly involve freedom of association, it indicated that such a freedom was guaranteed by the first amendment, and that it was incorporated in the due process clause of the fourteenth amendment.

Freedom of association clearly emerged in several cases involving the National Association for the Advancement of Colored People. ${ }^{83}$ In NAACP v. Alabama ex rel. Patterson, 84 the first of these cases, the Supreme Court explicitly recognized that the freedom to associate for the advancement of beliefs and ideas is an inseparable aspect of the liberty assured by the due process clause of the fourteenth amendment, and that any state action which may have the effect of curtailing this freedom will be closely scrutinized. ${ }^{85}$ Although the opinion speaks in terms of due process under the fourteenth amendment, the Court made it clear that through that amendment it was protecting the freedoms of the first amendment from state infringement. Freedom of association has also been seen as a derivative of the freedom to advance ideas, and thus linked to the first amendment. ${ }^{86}$ Such a relationship indicates that a court must be extremely careful to protect freedom of association when its infringement is claimed. 87

The Court in NAACP v. Alabama failed to specify whether freedom of association represented rights of the individual or of the organizational entity. The primary concern of the Court appeared to be that the disclosure of membership lists as required by an Alabama statute would expose the members to the possibility of adverse consequences, and thus affect their ability to pursue collective efforts to foster beliefs they had the right to advocate. ${ }^{88}$ On the other hand, there was also thought to be a reasonable likelihood that the association itself, through diminished finan-

81 Id. at 530; Note, 27 Geo. WASH. I. REv. 653, 656 (1959).

82 See Sweezy v. New Hampshire, 354 U.S. 234, 250-51 (1957); Fellman, Constitutional Rights of Association, 1961 SUPREME COURT REv. 74, 133.

83 Louisiana ex rel. Gremillion v. NAACP, 366 U.S. 293 (1961) ; Bates v. City of Little Rock, 361 U.S. 516 (1960); NAACP v. Alabama ex rel. 'Patterson, 357 U.S. 449 (1958).

84357 U.S. 449 (1958).

$85 I d$. at 460 .

86 Bates v. City of Little Rock, 361 U.S. 516, 522-23 (1960).

87 See NAACP v. Alabama ex rel. Patterson, 357 U.S. 449, 461 (1958); cf.

De Jonge v. Oregon, 299 U.S. 353, 364 (1937).

88 NAACP v. Alabama ex rel. Patterson, supra note 87, at 462-65. 
cial support and membership, would be adversely affected. ${ }^{89}$ In Bates $v$. City of Little Rock, ${ }^{90}$ the Supreme Court resolved this issue by determining that the rights encompassed by freedom of association were those of the individual, ${ }^{91}$ and that harm to the association would be considered an infringement of the rights of the individual members.

\section{B. Limitations on Freedom of Association}

Although freedom of association will be protected as a cognate of the first amendment rights to advance beliefs, it still is subject to a balancing test, $^{, 2}$ and where it conflicts with a greater public interest it may be constitutionally subordinated. This restriction is identical to that placed on freedom of speech, and is a corollary to all the first amendment freedoms which protect expression of ideas.

\section{Communism under the First Amendment}

Communism and the Communist Party have occupied a unique position in relation to the first amendment. Communist doctrine includes forcible overthrow of the government, and when advocacy of forcible action as opposed to advocacy of abstract doctrine, can be shown, such political expression will not be given first amendment protection. Since the Communist Party openly espouses Communist goals, it places itself and its members in a position readily conducive to abridgement of their first amendment freedoms. ${ }^{93}$

In the Communist Party case, for example, the Court recognized that a registration order and the various restrictions imposed by the act, which were immediately operative upon the order's becoming final, would infringe freedom of association by impairing a member's ability to espouse ideas effectively through the association. The Court found, however, that the interests of society in self-preservation outweighed the rights of the members of the association, and registration was thus justified.

\section{The Effect of the Infringement}

Although a court is more apt to justify restrictions on the rights of groups connected with Communism or the Communist Party than on ordinary associations, it by no means follows that abridgement of first amendment freedoms should be automatic where the Communist movement

89 Id. at $459-60$.

90361 U.S. 516 (1960).

91 See Note, 27 Geo. Wash. L. Rev. 653, 672 (1959) ; cf. Douglas, The Right of Association, 63 Colum. L. Rev. 1361, 1378 (1963).

92 See Uphaus v. Wyman, 360 U.S. 72, 80 (1959) ; Fellman, Constitutional Rights of Association, 1961 Supreme CourT Rev. 74, 134.

${ }^{93}$ See, e.g., Scales v. United States, 367 U.S. 203, 228-30 (1961); Communist Party v. SACB, 367 U.S. 1, 104-05 (1961); Barenblatt v. United States, 360 U.S. 109, 128 (1959); American Communications Ass'n v. Douds, 339 U.S. 382 (1950); Communist Party v. United States, 331 F.2d 807, 811 (D.C. Cir. 1963), cert. denied, 377 U.S. 968 (1964). 
is involved. The Communist Party case again may serve as an example, for in that case the registration order itself would not have had as great an effect on the association as disclosure of membership lists in the NAACP cases would have had on the members of that organization. The Communist Party did not contest the assertion that it was linked to the world Communist movement, and the primary thrust of the registration requirement was the simple reaffirmation of that relationship; in the NAACP cases, on the other hand, the members frequently desired to conceal their membership, and disclosure could have exposed them to community reprisal. The Communist Party case thus appears to have been a fairly easy one, and its implications consequently limited. The case did, however, involve by implication various restrictions which the act automatically invokes when an order to register becomes final, and to this extent there was much at stake for the association and its members.

That abridgement of first amendment rights even in this area will require a careful weighing of interests is highlighted more clearly by comparing two recent cases. In the first, American Communications Ass' $n v$. Douds, ${ }^{94}$ the Supreme Court held constitutional section $9(\mathrm{~h})$ of the National Labor Relations Act, ${ }^{95}$ which required union leaders to file affidavits disavowing any Communist affiliations. Failure to file such a statement would deprive the union of some of the benefits of the act. The Court based its decision on a determination that Congress could reasonably find that Communists, unlike members of other political parties, pose a constant threat of creating disruptive political strikes when they hold positions of union leadership. In the second case, Brown v. United States, ${ }^{98}$ however, the Ninth Circuit found that the 1959 amendment to 9 (h) ${ }^{97}$ prohibiting members of the Communist Party -or ex-members who have terminated their membership within five years-from holding union office violated freedom of association. The court distinguished Douds on the somewhat questionable basis of the different effects these statutes had on a Communist Party member's freedom of association. The court found the Brown statute to be too broad a restriction of freedom of association, analyzing it in terms of its general application and effect. In Douds the penalty applied directly to the union-withdrawing its rights to the benefits of the National Labor Relations Act. This sanction thus had only an indirect effect on the Party member, by the pressure which it placed on him through the union. In Brown, on the other hand, the sanction was a criminal prosecution which had a direct effect on the Party member's freedom of association. The court in Brown saw this direct effect as too great an infringement of the member's freedom of association to be justified by the congressional purpose, which was the same in both Brown and

94339 U.S. 382 (1950).

$95 \mathrm{Ch} .120,61$ Stat. 146 (1947) (repealed by 73 Stat. 525 (1959)).

86334 F.2d 488 (9th Cir.), aff'd, 85 Sup. Ct. 1707 (1965). In affirming the judgment of the Ninth Circuit, the Supreme Court did not reach the first amendment issue, but held instead that the statute was void as a bill of attainder.

87 Labor-Management Reporting and Disclosure Act § 504, 73 Stat. 536 (1959), 29 U.S.C. \$ 504 (Supp. V, 1964). 
Douds. This indicates that despite the relatively weak claim of Communist Party members to protection of their freedom of association, their rights must still be outweighed by some other interests to sustain a finding of infringement, and that the degree of the infringement will be a relevant consideration in the disposition of a case.

\section{Relation to the Communist Movement}

Douds and Brown involved an infringement of rights because of Communist Party membership. The question becomes a more difficult one where the Communist Party itself is not openly involved. The immediacy of the danger is not as apparent, and the evidentiary problems involved in showing linkage will frequently be extremely difficult.

In Uphans v. Wyman ${ }^{98}$ the Supreme Court indicated a willingness to permit states, through legislative investigations, to pry into the membership of associations alleged to be subversive. ${ }^{99}$ There was some evidence to show a nexus between the association in question and subversive activities, and although the Court did not regard the evidence as conclusive, a majority held it sufficient to support a contempt conviction for failure to produce guest lists of camp meetings. ${ }^{100}$ The Court in Uphaus stated that the lists in question were matters of public knowledge by reason of a guest registration statute to which camp visitors had voluntarily submitted. It may thus be questioned whether freedom of association was involved at all, since there may no longer have been any associational privacy to protect. $^{101}$ In addition, Uphaus may be seen as a case of an attempt to identify individual subversives, similar to cases involving contempt convictions for refusing to answer questions concerning one's own past or present membership in the Communist Party, ${ }^{102}$ rather than as an investigation into the association itself.

In Gibson v. Florida Legislative Investigation Comm., ${ }^{103}$ decided after the $U$ phaus case, the Court found an insufficient nexus between the NAACP and subversive activities to sustain a contempt conviction for refusal to divulge the contents of membership records of the Florida branch of the NAACP to a Florida legislative committee investigating infiltration of Communists into various organizations. In Gibson the evidence linking the NAACP with subversive activities was characterized by the Court as indirect, less than unequivocal, and mostly hearsay..$^{104}$ The majority spoke in terms of nexus, and would not go so far as to overrule the underlying

98360 U.S. 72 (1959). 74,121 .

99 See Feliman, Constitutional Rights of Association, 1961 SUPreme Court Rev.

100 The dissenters were Mr. Chief Justice Warren and Justices Black, Douglas and Brennan, all of whom are still on the court. Two members of the then majority, Justices Frankfurter and Whittaker, have since left the court. (1963).

101 See Gibson v. Florida Legislative Investigation Comm., 372 U.S. 539, 550

102 Ibid. Compare Braden v. United States, 365 U.S. 431 (1961); Wilkinson v.

United States, 365 U.S. 399 (1961) ; Barenblatt v. United States, 360 U.'S. 109 (1959). 103372 U.S. 539 (1963).

$104 I d$. at 555 . 
rationale of Uphaus that freedom of association may bow to legislative investigations even though the organization is pursuing activities which are protected by the first amendment. However, it is important to note that the majority, because of their resolution of the evidentiary issues, was not forced to face the constitutional issue. It is possible, however, that the resolution of the evidentiary issues was to some extent influenced by the factual context of the case, as the Court has shown a great solicitude for protecting the NAACP in the South.

Unlike Uphaus and Gibson, the Communist Party case did not present factual issues of linkage of the Party with the Communist movement. Congress itself had incorporated into the Internal Security Act legislative findings of the existence of a worldwide Communist movement whose aims included the overthrow of the Government, and which employed subversive methods to accomplish its goals. The Court did not question these findings, since they were amply documented by evidence accumulated in congressional investigations. ${ }^{105}$ Moreover, the board finding that the Communist Party was a communist-action organization was not seriously contested.

The Court recognized that a registration requirement as an incident to or a condition of the exercise of free speech may be unconstitutional, but found that the statute did not attach the registration requirement to an incident of speech, but rather to the incidents of foreign domination and activities in advancement of the objectives of the world Communist movement. Through this language the Court seemed to be balancing interests, concluding that the magnitude of the governmental interest involved-selfpreservation-justified the registration requirement. The Court also suggested that the concern for self-preservation would justify the disclosure of member's names. However, this suggestion was dictum, for at the outset of its opinion the Court was careful to point out that it was considering only the registration requirement itself, and not all the consequences which occur immediately upon a final order to register. The limited scope of the Communist Party case was made evident in Aptheker v. Secretary of State, ${ }^{106}$ where the Court held unconstitutional a denial of passport rights to a member of the Communist Party following a final order to register.

\section{Front Registration and the Constitution}

\section{The Constitutional Balance}

a. The Effect on the Association

Destruction of the organization is the likely effect of a registration order upon a Communist front. ${ }^{107}$ Because such organizations do not

105 See generally Note, 51 Colum. L. Rev. 606, 609-15 (1951), indicating that this is a not infrequent practice.

106378 U.S. 500 (1964).

107 See Chafee, The Blessings of Liberty 155 (1956). The author points out that by merely filing a petition with the Board, the Attorney General can put an 
operate in secret, their membership is either known or can easily be discovered. Consequently, the adverse publicity generated by a registration order would probably force the resignation of almost all non-Communist members. It might be argued that these individuals would resign upon learning of the Communist control even if there were no registration requirement. However, there might be members so dedicated to the organization's cause that they would retain their membership regardless of Communist control were it not for the coercive publicity engendered by a registration order.

When combined with the concomitant loss of tax-exempt status, the loss of membership will also decrease the financial resources of the association. In the NAACP cases the Supreme Court recognized that government action which diminishes financial support and membership abridges an individual's freedom of association. ${ }^{108}$ Moreover, a registration order will to some extent impair the association's ability to have its ideas accepted, as the present political climate leads to an automatic prejudice against ideas linked with Communism.

In Joint Anti-Fascist Refugee Comm. v. McGrath ${ }^{109}$ the Supreme Court held that the placing of an association on the Attorney General's list as a subversive organization gave the association standing to sue for declaratory and injunctive relief. Although there were several opinions, all of those written by the members of the majority agreed that the organization was deprived of constitutional rights by the listing. Justices Black and Douglas would have found the listing itself unconstitutional, but the other members of the majority based their opinions upon procedural and procedural due process grounds, the latter involving lack of notice and fair hearing. In the latest cases, ${ }^{110}$ the Court similarly failed-over a stinging dissent of Mr. Justice Douglas, joined by Justices Black and Harlan-to decide whether the registration provisions could constitutionally be applied to front organizations, and vacated the registration orders on the grounds of stale evidence. ${ }^{111} \mathrm{Mr}$. Justice Black, however, indicated that he would have held the entire act unconstitutional. ${ }^{112}$

organization under a cloud of suspicion, as well as force it to interrupt its activities in order to defend itself for extended periods at great cost. In the congressional debate, the opponents of the bill pointed to the fact that merely being brought before the Board would damage the reputation of an organization. Moreover, a board finding will burden an organization with a stigma which can not effectively be removed by a subsequent court reversal. See 96 CoNG. REc. 15712 (1950) (remarks of Senator Murphy).

108 See text accompanying note 89 supra.

${ }^{109} 341$ U.S. 123 (1951).

${ }_{110}$ American Comm. for Protection of Foreign Born v. SACB, 85 Sup. Ct. 1148

(1965); Veterans of the Abraham Lincoln Brigade v. SACB, 85 Sup. Ct. 1153 (1965).

111 See text accompanying note 38 supra.

112 I think that among other things the Act is a bill of attainder; that it imposes cruel, unusual and savage punishments for thought, speech, writing, petition and assembly; and that it stigmatizes people for their beliefs, associations and views about politics, law, and government. The Act has bor- 


\section{b. The Public Interest}

The registration of the Communist Party exposed to the public the link between a functioning organization and the Communist movement. The Communist front proceedings, however, have resulted mainly in forcing organizations to disband. Consequently, the public has not been given information about a presently existing organization, and the Communist movement is merely forced to reorganize and redeploy certain of its energies. Opponents of the bill in Congress argued that the effect of the act would be ultimately to drive the Communists further underground, ${ }^{113}$ and this was one of the major reasons President Truman gave for vetoing the act. ${ }^{114}$ In light of the rather doubtful results obtained by a registration order, one may question the vast amounts of time and energy expended in seeking such orders. After fifteen years, and twenty-two front proceedings, only six organizations have been finally ordered to register, and three of these claim they no longer exist.

The public interest involved in these cases is that of self-preservation, but it should be recognized that the nature of the threat posed to that interest by Communist fronts is quite different from that posed by communist-action organizations. If the immediate objectives of the latter were attained, violent overthrow of the Government would be the consequence. Such is not the case with communist-front groups, for their immediate objectives can only be attained through legal action within the context of

rowed the worst features of old laws intended to put shackles on the minds and bodies of men, to make them confess to crime, to make them miserable while in this country, and to make it a crime even to attempt to get out of it. It is difficult to find laws more thought-stifling than this one even in countries considered the most benighted. . . My vote is to hear the case now and hold the law to be what I think it is-a wholesale denial of what I believe to be the constitutional heritage of every freedom-loving American.

American Comm. for Protection of Foreign Born v. SACB, 85 Sup. Ct. 1148, 1155-56 (1965) (Black, J., dissenting). (Footnote omitted.)

113 See, e.g., 96 Cong. Rec. 13760 (1950) (remarks of Representative Jackson); id. at 14190 (remarks of Senator Lehman).

114 The president's veto message may be found at 96 CoNG. REc. 15629 (1950). The legislative history relative to the constitutionality of the act presents an amazing picture. It is clear that the act was prompted by the temper of the times-the nation was then fighting in Korea, eleven men had just been found guilty of violating the Smith Act in a widely publicized trial, and the Alger Hiss incident had recently come to light. A reading of the Congressional Record indicates how attuned to the times Congress was. See, e.g., 96 CoNG. REc. 13725-7 (1950) (remarks of Representative Rankin) ; id. at 13737 (remarks of Representative Wolverton) ; id. at 13738 (remarks of Representative Davis) ; $i d$. at 13745 (remarks of Representative Doyle); id. at 13748 (remarks of Representative Allen); id. at 14298 (remarks of Senator Wiley); $i d$. at 15647 (remarks of Senator Langer). The astonishing fact is that Congress was well aware that the act may have been unconstitutional, see, e.g., 96 CoNG. REc. 13745 (1950) (remarks of Representative Doyle); id. at 15701 (remarks of Senator Kefauver), but they were willing to pass the bill and leave it up to the courts to decide the question, because they feit the times demanded such action. Another factor motivating congressional support may well have been the labelling of the bill as anti-Communist, and the great danger a Congressman in the election year of 1950 would have run if he voted against a bill so labeled. See 96 Cong. REc. 13765 (1950) (remarks of Representative O'Hara); id. at 13768 (remarks of Representative Burdick). 
our present governmental system. Thus, even if front organizations are successful, the dangers they pose to society are not nearly as great as those threatened by a communist-action organization.

\section{The Present Law}

Since the NAACP cases, in which the Supreme Court for the first time squarely recognized and protected freedom of association, Uphaus $v$. Wyman is the only case not involving the Communist Party in which the Court has permitted that freedom to be reduced. Even in Uphaus, however, there was some question whether freedom of association was actually involved.115 Moreover, the concern of the state in that case was not the association itself, but the members of the Communist Party who might be in it. Since the Internal Security Act has separate provisions which enable the Government to seek the identity of Party members, ${ }^{116}$ registration of Communist fronts cannot be justified on this basis. The actual goal of the registration proceedings would thus appear to be the reduction of an organization's effectiveness as a purveyor of ideas. Such a reduction of the normal scope of first amendment rights has been permitted by the Court only in cases involving the Communist Party, and then only because that group advocated violent overthrow of the government. In front cases, the attempted reduction extends to organizations advocating constitutionally protected ideas, and the only justification is the showing of a purported link with the Communist Party. Only Uphaus found such a justification constitutionally sufficient to justify reduction, and that case is easily distinguished on its facts. The inescapable conclusion is that the Court is faced, in the communist-front cases, with a novel constitutional question.

\section{Overriding Constitutional Interests}

In any first amendment case, the Court must weigh the extent of the reduction and decide whether it is outweighed by the governmental interest involved. Frequently, however, the Court must look beyond this bare balance and gauge the effect of its decision upon society in general. ${ }^{117}$ The Communist front cases present this broader question, for they represent issues pivotal to a democracy.

By curtailing the operations of these organizations, the Government is to some extent stifling the free interchange of ideas. ${ }^{118}$. Because of the

115 See text accompanying note 101 supra.

116 See 64 Stat. 993-94 (1950), 50 U.S.C. \$ 786(d) (4) (1958) (registration of membership lists by association); 64 Stat. 995 (1950), 50 U.S.C. $\$ 787$ (1958) (registration by members of association if association does not register them).

117 This element is at the core of the "prophylactic" rules which have become part of the Constitution.

118 See Chafee, The Registration of "Commmist-Front" Organizations in the Mundt-Nixon Bill, 63 HARv. L. Rev. 1382, 1384-85 (1950). 
label "Communist front," an organization's ideas will not be measured by their intrinsic worth, but rather, to a great extent, by how the Government has labelled the advocate of those ideas. Where the ideas represent speech not protected by the first amendment, or where they aim at overthrowing the government, there may be a great public interest in seeing the advocate labelled and his background clearly exposed. ${ }^{119}$ When the ideas are protected by the first amendment, however, labelling becomes an unwarranted conditioning of the public mind by the Government. It would thus appear a very dangerous precedent to allow the Government to make the fine judgments involved here, ${ }^{120}$ for such decisions can have a great effect on the political thought of the nation. Because of the possibility of being labelled as a Communist front by the Government, an organization will be more reluctant to express views commonly held by the Communist Party. ${ }^{121}$ Nor is this necessarily limited to unpopular ideas, for an organization can be denominated a Communist front for advancing ideas the public may be ready to accept.

The first amendment freedom of political expression lies at the very heart of our system of government, and although not absolute, it should be tempered only in the extreme case. The Communist Party case was such an instance, for it involved a foreign-dominated organization whose avowed aim was the overthrow of the government. Beyond the area of criminal conspiracy in which the self-preservation argument may properly be invoked, there is no justification for requiring registration. Where the Government begins to limit the expression of ideas which pose no threat to self-preservation, and which represent speech protected by the first amendment, it has exceeded constitutional limits. As Mr. Justice Douglas has pointed out, ${ }^{122}$ there are a myriad of interlinkings between organizations in this nation, and it should not be the task of the Government to probe the intimacies of these relations. ${ }^{123}$ It has been well said that: (1951).

119 Cf. Sutheriand, Freedom and Internal Security, 64 HARv. L. REv. 383, 415-16

120 See Gellmorn, Amertcan Rights 87-89 (1960); Chafee, The Blessings OF LIBERTY 152-56 (1956); Chafee, The Registration of "Commutnist-Front" Organizations in the Mundt-Nixon Bill, 63 HARv. L. REv. 1382, 1388-89 (1950). Professor Gellhorn points out that perils which are sought to be suppressed are regularly overestimated, and society should conserve its strength for real problems. He argues that where immediacy of danger is not the test, boundaries will become increasingly difficult to draw. GELLHORN, op. cit. supra at 83-84. The opponents of the bill in Congress insisted that the real danger of Communism lay in espionage and sabotage, and that the bill did not begin to reach these dangers. See, e.g., 96 CoNG. REC. 14405 (1950) (remarks of Senator Douglas); $i d$. at 15525 (remarks of Senator Humphrey).

121 This aspect of the statute, in effect making the extent of adherence to views expressed by the Soviet Union one of the tests for whether or not an organization is a Communist front, is severely criticized by Professor Gellhorn. GeLrHORN, op. cit. supra note 120, at 89 . See also sources cited in note 43 supra.

122 Gibson v. Florida Legislative Investigation Comm., 372 U.S. 539, 565 (1963) (concurring opinion).

123 See Chafee, The Registration of "Conmunist-Front" Organizations in the Mundt-Nizon Bill,'63 HARV. L. REv. 1382, 1387 (1950). 
[I] t cannot be the duty, because it is not the right, of the state to protect the public against false doctrine. The very purpose of the First Amendment is to foreclose public authority from assuming a guardianship of the public mind through regulating the press, speech and religion. In this field every person must be his own watchman for the truth, because the forefathers did not trust any government to separate the true from the false for us. ${ }^{124}$

\section{Lawrence J. Rothenberg}

124 Thomas v. Collins, 323 U.S. 516, 545 (1945) (Jackson, J., concurring). 